\title{
Exposure to Pesticide and Its Association With Respiratory Health Among Paddy Farmers at TanjungKarang, Selangor
}

\author{
Juliana Jalaludin ${ }^{1,2}$, Nuranis Syfainie Mohd Samsuddin ${ }^{1} \&$ Abdul Rohim Tualeka ${ }^{2}$ \\ ${ }^{1}$ Department of Environmental and Occupational Health, Faculty of Medicine and Health Sciences, Universiti \\ Putra Malaysia, Serdang, Malaysia \\ ${ }^{2}$ Department of Occupational Health and Safety, Faculty of Public Health, Airlangga University, East Java, \\ Indonesia \\ Correspondence: Juliana Jalaludin, Department of Environmental and Occupational Health, Faculty of Medicine \\ and Health Science, Universiti Putra Malaysia, Serdang 43400, Selangor, Malaysia. Tel: 603-8947-2397. E-mail: \\ juliana@upm.edu.my
}

Received: January 17, 2019 Accepted: March 12, 2019 Online Published: March 19, 2019

doi:10.5539/gjhs.v11n4p104 URL: https://doi.org/10.5539/gjhs.v11n4p104

\begin{abstract}
Pesticide has been used by paddy farmers in their agricultural activities to increase rice crop yield since past few decades. However, the usage of this chemical with limited knowledge of its deleterious effects on health, community and environment without proper consideration of safety may cause chronic health problems such as respiratory health problems and lung dysfunction. This paper was conducted to determine the association of exposure to pesticide with respiratory health among paddy farmers at TanjungKarang, Selangor as exposed group and office workers working in TanjungKarang town as the comparative group. The results showed that the duration of exposure to pesticide between both groups were mostly low $(86 \%)$ and high duration for only $4 \%$ for paddy farmers and none of office workers. There were significant differences in cough and phlegm, as they were higher among paddy farmers compared to the comparative group at $\rho<0.001$. Paddy farmers who were exposed to high levels of pesticide were 2 times more likely to have cough and 3 times more likely to get phlegm. FVC\% $(\mathrm{t}=-1.470, \mathrm{p}=0.001)$ and $\mathrm{FEV}_{1} \%(\mathrm{t}=-1.526, \mathrm{p}=0.001)$ were lower among the exposed group compared to the comparative group. The prevalence of abnormal FVC were found at $80 \%$ in exposed group and $38 \%$ in comparative group andabnormal $\mathrm{FEV}_{1}$ were found at $89 \%$ and $31 \%$ of respondents in both study groups. There was a significant correlation between long abnormalities for $\mathrm{FVC} \%$ and exposure duration $\left(\chi^{2}=2.903, \mathrm{p}=0.001\right)$. This study concluded that the paddy farmers were at risk of respiratory symptoms, as reflected by the increase in the reported respiratory symptoms and lung function reduction.
\end{abstract}

Keywords: lung function, pesticides, respiratory health problem, spirometry

\section{Introduction}

Pesticide use in crop production such as paddy has been suspected of being one of the contributions to the environmental pollution (Parveen \& Nakagoshi, 2001). Studies have shown that less than $0.1 \%$ of the pesticide that were applied during the agricultural activities that actually reach the target pest, where the remainder spreading out into the environment (Baharuddin et al., 2011; Greene, 2013). There are widespread and growing concerns of pesticide usage, with consequent effects on the contamination of ground water, surface water, soils and food and impacts on the wildlife and human health (Baharuddin, Sahid, Noor, Sulaiman, \& Othman, 2011; Nur Naqibah et al., 2017; McLaughlin \&Mineau, 1995).

Many researchers discuss on the improper and excessive use of pesticides, especially in developing countries, are due to the lack of proper education and training provided to the farmers and workers in pesticide use, lack of alternatives other than pesticides, poor information on the related health effects, stringent market requirements for crop aesthetic perfection, and also due to the unwillingness of the farmers to handle the risk of crop loss (Hashemi \& Damalas, 2010; Khan, Mahmood, \& Damalas, 2015; Wilson \& Tisdell, 2001). A study conducted by Schreinemachers et al. (2017) indicated that lack of knowledge on the usage of pesticides and widespread pesticide use for lower income countries such as Cambodia and Laos were due to the weak regulatory frameworks and monitoring systems than those in higher income countries (McCann, 2005; Schreinemachers et al., 2015). Higher levels of education, gives these farmers and workers a better knowledge and information about how to use and 
handle pesticides (Shetty et al., 2010). While less educated farmers may be experienced difficulty and limitation to access the information on pesticides and to follow recommended safety and application guidelines (Matthews, 2008).

Handlers of pesticide such as paddy farmers are at risk of exposure to this hazardous residues during mixing and application of the pesticide during agricultural activities, through inhalation, skin contact and also ingestion (Baharuddin et al., 2011). Long term exposure to pesticides without proper consideration for safety when managing the pesticide activities may cause chronic health problems such as cancer, respiratory health problem, liver abnormalities, and lung dysfunction (Kaplan, 2002). According to Hoppin et al. (2006), exposure to paraquat pesticide has been related to the initiation of respiratory symptoms such as dyspnea, dry cough, along with chest pain, wheezing, difficulty in breathing, runny nose and throat irritation.

Exposure to pesticides has been linked to numerous health disorder other than respiratory problem. A review study conducted by Sabarwal, Kumar and Singh (2018)found many other adverse health effects that associated with pesticides, such as Hodgkin's disease (HD), non-Hodgkin lymphoma (NHL) (Luo et al., 2016; Wiklund, Dich, \& Holm, 1987); Parkinson's disease (Brouwer et al., 2017; Wang, Cockburn, Ly, Bronstein, \& Ritz, 2014); endocrine disruption (Freire et al., 2013; Mazur, Marchitti, \& Zastre, 2015);respiratory diseases such as chronic obstructive pulmonary disease, asthma, and hypersensitivity pneumonitis (Bonner et al., 2016); and reproductive disorders (Lerro et al., 2018; Luo et al., 2017; Waheed et al., 2017). Poisoning from pesticides has become a global public health problem and accounts for nearly 300,000 deaths every year (Sabarwal, Kumar, \& Singh, 2018). Dhananjayan and Ravichandran (2018) also conclude in their review study that pesticides can caused negative health effects which include various types of cancer, dermatological, gastrointestinal, neurological, respiratory and reproductive effects.

TanjungKarang is a paddy growing town located in Selangor, Malaysia. Therefore, paddy farmers here are also using pesticide to control pests in their agricultural activities. In the paddy growing areas in Malaysia, the herbicide paraquat is the most commonly used by the farmers (Halimah, Nashriyah, Tan, \& Ismail, 2004). Paraquat has been listed under Class II by the World Health Organization (WHO, 2009) classification, which is known as moderately hazardous to human health. While the fights against the pests are mostly won by an extensive usage of pesticides, however, there is no study that is related to the personal exposure to pesticides and it is effect on lung function among paddy farmers in Malaysia. Thus, this study was conducted to determine the magnitude of exposure to pesticide among paddy farmers in this area, with their respiratory health and lung function. After presentation of the results of the assessment, appropriate recommendations are proposed.

\section{Material and Methods}

\subsection{Study Location/Study Population}

This study was carried out at the paddy field area located in Kampung SawahSempadan, Selangor. This cross sectional comparative study was conducted among 74 paddy farmersas who used pesticides during their working activities, aged 25-60 years old, who were working in agricultural field for at least 10 years. This exposed group were non-smoker, male, and those who suffer from chronic disease and history of respiratory problems were not included in this study. Meanwhile, 74 office workers who worked in administrative office were used as the comparative group.

\subsection{Instruments and Procedures}

The questionnaires used were adopted from The American Thoracic Society (ATS, 1991). The questionnaire was pretested by using Cronbach's alpha reliability test (Result: $\alpha=0.825$ ) and the total respondents for the pretest were $10 \%$ of the sample size. The questionnaire also included demographic questions and medical history of the respondents. Another self-administered questionnaires were used to obtain information on the working activities of the paddy farmers, including the type of pesticide used, amount of pesticide and duration of pesticide used. Spirometer model Chestograph II-701 was used to conduct a lung function test among the paddy farmers (ATS, 1991). The evaluation of lung function test was performed by comparing the obtained value with normal values (standard value).

\subsection{Frequency and Duration of Exposure to Pesticide}

The degree of exposure to pesticide among the respondents were evaluated by using frequency rating and duration rating suggested by Chemical Health Risk Assessment Manual (CHRA, 2000) under USECHH Regulation. This method showed that the more frequent or the longer the duration of hazardous chemical being used, the higher the degree of exposure. Table 1 and Table 2 showed the frequency and duration ratings. 
Table 1. Frequency rating

\begin{tabular}{lll}
\hline Rating & Description & Definition \\
\hline \multirow{2}{*}{ High } & Frequent & Potential exposure one or more time per shift or per day \\
\multirow{2}{*}{ Moderate } & Probable & Exposure greater than one per week \\
\multirow{2}{*}{ Low } & Occasional & Exposure greater than one time per month \\
& Remote & Exposure greater than one time per year \\
\hline
\end{tabular}

Sources: Chemical Health Risk Assessment Manual 2nd Edition (CHRA, 2000).

Table 2. Duration rating

\begin{tabular}{lll}
\hline \multirow{2}{*}{ Rating } & \multicolumn{2}{l}{ Total Duration of Exposure* } \\
\cline { 2 - 3 } & $\%$ Work hour & Duration per 8 -hr shift or per 40 -hr week \\
\hline \multirow{2}{*}{ High } & $>87.5 \%$ & $>7 \mathrm{hrs} /$ shift or $>35$ hours/ week \\
\multirow{2}{*}{ Moderate } & $50-87.5 \%$ & 4 to $7 \mathrm{hrs} /$ shift or 20 to 35 hours/ week \\
\multirow{2}{*}{ Low } & $25-50 \%$ & 2 to $4 \mathrm{hrs} /$ shift or 10 to 20 hours/ week \\
& $12.5-25 \%$ & 1 to $2 \mathrm{hrs} /$ shift or 5 to 10 hours/ week \\
\hline
\end{tabular}

Sources: Chemical Health Risk Assessment Manual 2nd Edition (CHRA, 2000).

*Total exposure duration per week $=($ Number of exposure per week $) \times($ Average duration of each exposure $)$.

\subsection{Data Analysis}

The collected data was analyzed by using the statistical package SPSS version 21 . To study the association and differences between duration of exposure to pesticide and the respiratory health of respondents, $t$-test, Man-Whitney $U$ test, Chi-square test and Spearman Rho test were used.The multiple regression test was performed to determine the main variables that influence the lung function of the respondents. The statistical result of $p<0.05$ represents statistically significant data.

\section{Results and Discussions}

\subsection{Sociodemographic Data of Respondents}

The findings for the sociodemographic data of the respondents were presented in Table 3. From the questionnaire forms, the aged of respondents for both of study groups were ranged from 25-60 years old. The mean age for exposed group was $41.501 \pm 5.906$ years and $39.865 \pm 5.297$ years for comparative group. The mean height of the respondents from exposed group was $166.652 \pm 6.781 \mathrm{~cm}$ compared to $167.234 \pm 4.861 \mathrm{~cm}$ for comparative group. Meanwhile, the mean weight of exposed group was obtained at $75.774 \pm 9.312 \mathrm{~kg}$ and $74.301 \pm 9.612 \mathrm{~kg}$ for comparative group. There were $58.1 \%$ (43 respondents) among paddy farmers and 52.7\% (39 respondents) among office workers were smokers. As for the work duration (year), the mean was $21.72 \pm 13.000$ for paddy farmers and $18.98 \pm 9.000$ for office workers. Results from the t-test showed that there were no significant difference in age, height, weight as well as in duration of work between two study groups. According to Krider and Sheldon (2000), factors such as race, age, gender, height and weight are the important factors that can influence the prediction of lung function parameters among the study respondents. 
Table 3. Sociodemographic data between paddy farmers and comparative group

\begin{tabular}{lllll}
\hline \multirow{2}{*}{ Variables } & $\begin{array}{l}\text { Exposed Group } \\
(\mathbf{n = 7 4 )}\end{array}$ & Comparative Group & \multirow{2}{*}{ z/t Value } & p Value \\
\cline { 2 - 3 } & Mean \pm SD & Mean \pm SD & 1.395 & 0.165 \\
\cline { 1 - 3 } Age( years) & $41.501 \pm 5.906$ & $39.867 \pm 5.297$ & 0.2167 & 0.567 \\
Height (cm) & $166.65 \pm 6.781$ & $167.231 \pm 4.861$ & 1.386 & 0.169 \\
Weight (Kg) & $75.772 \pm 9.312$ & $74.306 \pm 9.612$ & & \\
Smoking Habits & & & & \\
Yes & $43(58.10)$ & $39(52.70)$ & -0.050 & 0.960 \\
No & $31(41.89)$ & $35(47.29)$ & -1.975 & 0.433 \\
Work Duration & $21.723 \pm 13.000$ & $18.982 \pm 9.00$ & & \\
\hline
\end{tabular}

$\mathrm{N}=148$, Statistic Mann Whitney-U test *Significant at $\mathrm{p}<0.05$.

\subsection{Frequency and Duration of Exposure to Pesticide}

The findings from this study as shown in Table 4 indicated that majority of the respondents from exposed group experienced moderate frequency of exposure to pesticide at $75.67 \%$ (56 respondents) while $91.89 \%$ (68 respondents) from comparative group exposed to low frequency of exposure due to unrelated to agricultural sector. $8.1 \%$ (6 respondents) of the respondents among the comparative group that exposed to pesticide were from dietary, accidental exposure in public areas and due to the location of their houses that located near to paddy fields. The findings from this study were similar with the studies conducted in India among agricultural workers (Chakraborty et al., 2009) where the control group were being exposed to pesticide that were detected in environment, food stuffs, variety of fruits, winter vegetables and milk.

Meanwhile, the duration of exposure were low for both study groups, both at $86.48 \%$ ( 64 respondents). Only $4.05 \%$ ( 3 respondents) from paddy farmers that were experienced a high duration of exposure. There was no significant difference in frequency and duration of exposure to pesticide between the paddy farmers and office workers. The findings for this data were summarized in Table 5.

Table 4. Frequency of exposure to pesticides betweenpaddy farmers and comparative group

\begin{tabular}{|c|c|c|c|c|}
\hline Frequency of Exposure to Pesticides & $\begin{array}{l}\text { Exposed Group } \\
(n=74)\end{array}$ & $\begin{array}{l}\text { Comparative Group } \\
(\mathrm{n}=74)\end{array}$ & $\chi^{2}$ & p value \\
\hline & Number (\%) & Number (\%) & & \\
\hline High & $2(2.70)$ & $0(0.00)$ & 1.27 & 0.260 \\
\hline Moderate & $56(75.67)$ & $6(8.10)$ & & \\
\hline Low & $16(21.62)$ & 68(91.89) & & \\
\hline
\end{tabular}

$\mathrm{N}=148$, Statistic Mann Whitney-U test *Significant at $\mathrm{p}<0.05$.

Table 5. Duration of exposure to pesticides betweenpaddy farmers and comparative group

\begin{tabular}{|c|c|c|c|c|}
\hline Duration Exposure of Pesticides (weeks) & $\begin{array}{l}\text { Exposed Group } \\
(n=74)\end{array}$ & $\begin{array}{l}\text { Comparative Group } \\
(n=74)\end{array}$ & $\chi^{2}$ & p value \\
\hline & Number (\%) & Number (\%) & & \\
\hline High & $3(4.05)$ & $0(0.00)$ & & \\
\hline Moderate & $7(9.45)$ & $7(13.52)$ & 1.42 & 0.29 \\
\hline Low & $64(86.48)$ & $64(86.48)$ & & \\
\hline
\end{tabular}

$\mathrm{N}=148$, Statistic Mann Whitney-U test $*$ Significant at $\mathrm{p}<0.05$. 


\subsection{Prevalence of Respiratory Symptoms}

Four parameters of respiratory symptoms were assessed in this study, where were identified by using standardized and validated questionnaires. Questions asked included cough, phlegm, wheezing, and chest tightness experienced by the respondents. Table 6 showed that most of the paddy farmers $(56.75 \%)$ were reported to have cough (42 of them) as compared to 18 of office workers (24.32\%). Other symptom such as phlegm where 29 of paddy farmers $(39.18 \%)$ and 11 of office workers $(14.86 \%)$ were recorded to have this symptom. Wheezing was another symptom that occurred among exposed group with 14 of recorded cases (18.91\%) and 4 cases for comparative group (5.4\%). Another respiratory health symptom was chest tightness where 11 of respondents from exposed group (14.86\%) and 5 respondents from control group $(6.75 \%)$ were reported to experience this symptom.

The findings from this study were supported by Bayrami et al. (2012) in their study of work-related symptoms among Iranian farmers whereusage of pesticides was associated with the increased of wheezing and phlegm risk. Similar findings were also obtained by Neghab et al. (2014) where higher prevalence of respiratory symptoms was observed among pesticide formulating company workers as compared to the comparative group. Significant difference was obtained for cough $(\mathrm{OR}=8, \mathrm{p}=0.004)$, phlegm $(\mathrm{OR}=6.4, \mathrm{p}=0.004)$ and wheezing $(\mathrm{OR}=13.6$, $\mathrm{p}=0.02)$.

Table 6. Comparison of respiratory symptoms between exposed and control groups

\begin{tabular}{|c|c|c|c|c|c|c|}
\hline \multirow[t]{2}{*}{ Variables } & $\begin{array}{l}\text { Exposed Group } \\
(n=74)\end{array}$ & $\begin{array}{l}\text { Comparative } \\
\text { Group } \\
(n=74)\end{array}$ & \multirow[t]{2}{*}{$\chi^{2}$} & \multirow[t]{2}{*}{$P$ value } & \multirow[t]{2}{*}{ PR } & \multirow[t]{2}{*}{$95 \% \mathrm{CI}$} \\
\hline & Total (\%) & & & & & \\
\hline \multicolumn{7}{|l|}{ Cough } \\
\hline Yes & $42(56.75)$ & $18(24.32)$ & 16.15 & $0.001 *$ & 4.08 & $2.02-8.24$ \\
\hline No & $32(43.24)$ & $56(75.67)$ & & & & \\
\hline \multicolumn{7}{|l|}{ Phlegm } \\
\hline Yes & $29(39.18)$ & $11(14.86)$ & 11.10 & 0.001* & 3.69 & $1.67-8.15$ \\
\hline No & $45(60.81)$ & $63(85.13)$ & & & & \\
\hline \multicolumn{7}{|l|}{ Wheezing } \\
\hline Yes & $14(18.91)$ & $4(5.40)$ & 6.32 & 0.21 & 4.08 & $1.28-13.07$ \\
\hline No & $60(81.08)$ & $70(94.59)$ & & & & \\
\hline \multicolumn{7}{|l|}{ Chest } \\
\hline \multicolumn{7}{|l|}{ tightness } \\
\hline Yes & $11(14.86)$ & $5(6.75)$ & 2.52 & 0.18 & 2.41 & $0.79-7.32$ \\
\hline No & $63(85.13)$ & 69(93.24) & & & & \\
\hline
\end{tabular}

$\mathrm{N}=148$, Statistic Mann Whitney $\mathrm{U}$ test $*$ Significant at $\mathrm{p}<0.05$.

\subsection{Comparison of Lung Function}

Results from the statistical analysis showed that the lung function among comparative group was higher as compared to exposed group. Findings from the analysis showed that all lung function parameters (FVC, $\mathrm{FEV}_{1}$, $\mathrm{FVC} \%$ and $\mathrm{FEV}_{1} \%$ ) were higher for the comparative group as compared to the studied group except for the $\mathrm{FEV}_{1} / \mathrm{FVC} \%$ as showed in Table 7. There were significant differences in $\mathrm{FVC} \%$ and $\mathrm{FEV}_{1}(\%)$ between exposed and comparative group.Results from this study were consistent with the study conducted by Peiris -John et al. (2004) in Sri Lanka. The reading of the parameters $\left(\mathrm{FVC}\right.$ and $\left.\mathrm{FEV}_{1}\right)$ were significantly lower $(\mathrm{p}<0.001)$ among studied group, both between and during the exposure periods to organophosphate (OP) pesticide.

Lung is the primary target organ of all inhaled toxicants and reasonable to assume that the function of this organ might be affected following pesticide exposure via inhalation (Davidson et al., 2002). In addition, neurological effects caused by cholinesterase inhibiting pesticides such as OPs and carbamates also has been recognized to 
affect lung and airways, leading to respiratory symptoms, impaired lung function and respiratory disease (Ming Ye et al., 2013).A study by Khane and Arora (2015)found that the effect of inhaled pesticide on pulmonary function among 150 farm workers as studied group reported significant reduction $(\mathrm{p}<0.05)$ in FVC, FEV ${ }_{1}$, PEFR and MVV as compared to control group.The results from this study also indicated that pesticide exposure increase airway resistance, increasing closing volume and reversible reduction of FVC.Similar trend was obtained in a study by Chakraborty et al. (2009)where they found that agricultural workers in India had 13.6\% less mean of FVC, 15.6\% less mean of $\mathrm{FEV}_{1}, 5 \%$ decline in $\mathrm{FEV}_{1} / \mathrm{FVC}$ ratio, $20 \%$ decline in mid-expiratory flow rate $\left(\mathrm{FEF}_{25 \%-75 \%}\right)$ and $25 \%$ reduction in PEFR and concluded that Acetylcholinerase (AChe) inhibition was positively associated with decline in FVC.

Table 7. Comparison of lung functions between exposed and comparative group

\begin{tabular}{llllc}
\hline Variables & $\begin{array}{l}\text { Exposed group } \\
(\mathbf{n}=\mathbf{7 4})\end{array}$ & $\begin{array}{l}\text { Comparative group } \\
(\mathbf{n}=\mathbf{7 4})\end{array}$ & Z/t value & P value \\
\hline FVC & $2.34 \pm 0.61$ & $2.61 \pm 0.72$ & -0.405 & 0.686 \\
FEV $_{\mathbf{1}}$ & $2.08 \pm 0.75$ & $2.13 \pm 0.59$ & -0.457 & 0.649 \\
FVC\% & $70.05 \pm 27.84$ & $75.74 \pm 18.27$ & -1.470 & $\mathbf{0 . 0 0 4 *}$ \\
FEV $_{\mathbf{1}} \%$ & $77.84 \pm 31.97$ & $84.75 \pm 22.18$ & -1.526 & $\mathbf{0 . 0 1 7 ^ { * }}$ \\
FEV $_{\mathbf{1}} / \mathbf{F V C \%}$ & $111.78 \pm 9.03$ & $111.43 \pm 11.79$ & -0.206 & 0.837 \\
\hline
\end{tabular}

$\mathrm{N}=148$, Statistic Mann Whitney U test *Significant at $\mathrm{p}<0.05$.

\subsection{Comparison of Lung Function Status}

Based on the data analysis through the questionnaire forms, the lung function status among paddy farmers showed $59(79.72 \%)$ and 66 respondents $(89.18 \%)$ had abnormal statuses for $\mathrm{FVC} \%$ and $\mathrm{FEV}_{1} \%$ respectively, while 28 (37.83\%) and 23 respondents (31.08\%) were having abnormal statuses for both $\mathrm{FVC} \%$ and $\mathrm{FEV}_{1} \%$ among office workers. Both parameters of lung function showed significant differences as showed in Table 8 . However, there was no significant difference between two studies groups for $\mathrm{FEV}_{1} / \mathrm{FVC}$ parameter.

Table 8. Comparison of lung function status between exposed and comparative group

\begin{tabular}{|c|c|c|c|c|c|c|}
\hline \multirow[b]{2}{*}{ LungFunction } & \multicolumn{2}{|c|}{ Exposed $(n=74)$} & \multicolumn{2}{|c|}{ Comparative $(n=74)$} & \multirow{2}{*}{$\begin{array}{l}\chi^{2} \\
(\%)\end{array}$} & \multirow{2}{*}{$\begin{array}{l}\text { p value } \\
(\%)\end{array}$} \\
\hline & $\begin{array}{l}\text { Abnormal } \\
(\%)\end{array}$ & $\begin{array}{l}\text { Normal } \\
\text { (\%) }\end{array}$ & $\begin{array}{l}\text { Abnormal } \\
(\%)\end{array}$ & $\begin{array}{l}\text { Normal } \\
(\%)\end{array}$ & & \\
\hline FVC\% & $59(79.72)$ & $15(20.27)$ & $28(37.83)$ & $46(62.16)$ & 26.80 & 0.001* \\
\hline $\mathrm{FEV}_{1} \%$ & $66(89.18)$ & $8(10.81)$ & $23(31.08)$ & $51(68.91)$ & 52.11 & $0.001 *$ \\
\hline FEV $_{1} /$ FVC & $4(5.40)$ & $70(94.59)$ & $0(0.00)$ & $74(100)$ & 4.11 & 0.120 \\
\hline
\end{tabular}

$\mathrm{N}=148, *$ Significant at $\mathrm{p}<0.05$.

\subsection{Association between Duration Exposures to Pesticide with Respiratory Symptoms among Paddy Farmers}

Results from the analysis showed that there were significant association between duration of exposure to pesticide with respiratory symptoms that were assessed in this study. Based on Table 9, paddy farmers who were exposed to high duration of exposure were 3 times more likely to get cough and phlegm, 2 and 4 times more likely to get wheezing and chest tightness.

A similar trend was obtained in a study by Schenker et al. (2004), where there was a significant difference of chronic respiratory symptoms such as cough, chest tightness, wheezing and phlegm between farm workers group and the comparative group. The researcher also found a higher prevalence of respiratory symptom such as cough when duration of work exceeds 10 years. This findings supported that respiratory symptoms are more obvious with prolonged exposure to pesticide among agricultural workers. 
Table 9. The association of between duration of exposures to pesticides with respiratory symptoms among paddy farmers

\begin{tabular}{|c|c|c|c|c|c|}
\hline \multirow[t]{2}{*}{ Variables } & $\begin{array}{l}\text { Pesticide } \\
\text { (high) }\end{array}$ & $\begin{array}{l}\text { Pesticide } \\
\text { (moderate) }\end{array}$ & $\begin{array}{l}\text { Pesticide } \\
\text { (low) }\end{array}$ & \multirow[t]{2}{*}{$\chi^{2}$} & \multirow[t]{2}{*}{ P value } \\
\hline & \multicolumn{3}{|l|}{ Total (\%) } & & \\
\hline \multicolumn{6}{|l|}{ Cough } \\
\hline Yes & $2(2.70)$ & $5(6.75)$ & $35(47.29)$ & 17.74 & $0.001 *$ \\
\hline No & $1(1.35)$ & $2(2.70)$ & $29(39.18)$ & & \\
\hline \multicolumn{6}{|l|}{ Phlegm } \\
\hline Yes & $1(1.35)$ & $4(5.40)$ & $24(32.43)$ & 13.23 & $0.004 *$ \\
\hline No & $2(2.70)$ & $3(4.05)$ & $40(54.05)$ & & \\
\hline \multicolumn{6}{|l|}{ Wheezing } \\
\hline Yes & $1(1.35)$ & $2(2.70)$ & $11(14.86)$ & 10.87 & 0.012* \\
\hline No & $2(2.70)$ & $5(6.75)$ & $53(71.62)$ & & \\
\hline \multicolumn{6}{|c|}{ Chesttightness } \\
\hline Yes & $1(1.35)$ & $3(4.05)$ & $7(9.45)$ & 18.81 & $0.001 *$ \\
\hline No & $2(2.70)$ & $4(5.40)$ & $57(77.02)$ & & \\
\hline
\end{tabular}

$\mathrm{N}=148,{ }^{*}$ Significant at $\mathrm{p}<0.05$.

\subsection{Association between Duration Exposures to Pesticide and Lung Function (FVC \% and FEV \%)among Paddy Farmers}

Based on data analysis on the correlation between duration of exposure to pesticide with lung function (FVC \%) as shown in Table 10, there were significant association among both exposed group and comparative group. Paddy farmers who were exposed to high level of pesticide were 2 times more likely to have an abnormality of FVC \%. Results from this analysis showed that there was increased in the risk of lung function reduction among paddy farmers when exposed to high exposure duration to pesticide. Findings from this study were similarly with the previous research conducted by Chakraborty et al. (2009)where they found that at low level of exposure duration to pesticide has led to lung dysfunction among studied group who occupationally exposed to pesticide.

Meanwhile, as for $\mathrm{FEV}_{1} \%$, there was no statistical significant with duration exposure to pesticide among paddy farmers (Table 11). This is due to the paddy season where after the first season ended, farmers will be at rest for about 3 months until the next season. During this resting time, some farmers will continue to use pesticide for another crops and usually will perform several tasks within this period. Therefore, this might influenced the findings in this study. Besides, all respondents were not exposed or handled the pesticide at the same quantities and types.Evaluating effects of pesticides on lung function therefore faced a challenge farmers were typically exposed to many other respiratory irritant and toxicants such as crop components and animal debris.

This result was supported bySham'a et al. (2015) where the study found no association between exposure indicators of pesticides or dust and cross-shift changes in lung function among 195 male farmers in Palestinian. Dalvie et al. (1999)also reported that there were no significant correlation between exposures to paraquat and self-reported respiratory or changes in pulmonary function among 41 subjects of fruits farmers when compared to 70 subjects from the control group. 
Table 10. The Association between Duration of Exposure to Pesticide and Lung Function (FVC \%) among Paddy Farmers

\begin{tabular}{lllll}
\hline \multirow{2}{*}{ Variables } & \multicolumn{2}{c}{ Lung Function } & & \\
\cline { 3 - 4 } & Abnormal & Normal & $\chi^{2}$ & p value \\
\hline Durationexposure (week) & & & \\
\hline High & $2(2.70)$ & $1(1.35)$ & 2.903 & $\mathbf{0 . 0 0 1 *}$ \\
Moderate & $4(5.40)$ & $3(4.05)$ & & \\
Low & $53(71.62)$ & $11(14.86)$ & & \\
\hline
\end{tabular}

$\mathrm{N}=148, *$ Significant at $\mathrm{p}<0.05$

Table 11. The Association between Duration of Exposure to Pesticide and Lung Function ( $\mathrm{FEV}_{1} \%$ ) among Paddy Farmers.

\begin{tabular}{lllll}
\hline \multirow{2}{*}{ Variables } & \multicolumn{2}{c}{ Lung Function } & & p value \\
\cline { 3 - 4 } & Abnormal & Normal & & \\
\cline { 1 - 3 } Duration exposure (weeks) & $3(4.05)$ & $0(0.00)$ & 0.452 & 0.798 \\
\hline High & $1(1.35)$ & $6(8.10)$ & & \\
Moderate & $57(77.02)$ & $7(9.45)$ & & \\
\hline
\end{tabular}

$\mathrm{N}=148,{ }^{*}$ Significant at $\mathrm{p}<0.05$.

\subsection{Correlation between Working Duration (Years) and Lung Function Parameters among Paddy Farmers}

Data analysis in Table 12 showed the results from the statistical analysis of Spearman Rho test in order to determine the association of working duration of the paddy farmers with the lung function parameters. From the findings in this study, there were significant relationships between working duration with all the lung function parameters among the respondents.

The results from this study were found to be similar with the findings obtained by Chakraborty et al. (2009)where they conducted a research among 376 agricultural workers as exposed group in India. They found that when the exposure duration (years) to pesticide increased, the Acetylholinerase (AChe) activities and lung function among agricultural workers were decreasing when compared to the control group $(R h o=-0.526 ; p<0.001)$.

According to Kodavantiet al. (1999), the effects of pesticide exposure on respiratory health depends on several factors. These include the level of exposure, susceptibility and the subject's characteristics such as age, gender, underlying disease, smoking, physiological and social status, genetic and nutritional deficiencies. Besides, it has been well established that the elderly and young children were found to be more susceptible to the effects on pesticides exposure on mortality, morbidity and reduction in lung function than the remainder of the population(Salameh et al., 2004). Subjects with preexisting cardiovascular and respiratory disease are also at higher risk (Dockery, 2001; Dockery et al., 1993). 
Table 12. Correlation between working duration (years) and the lung function parameters among paddy farmers.

\begin{tabular}{lll}
\hline \multirow{2}{*}{ Variables } & \multicolumn{2}{l}{ Working duration (years) } \\
\cline { 2 - 3 } & Exposed group (n=74) \\
\cline { 2 - 3 } & r value & P value \\
\hline FVC & -0.441 & $\mathbf{0 . 0 0 0 *}$ \\
FEV1 & -0.491 & $\mathbf{0 . 0 3 1 ^ { * }}$ \\
FVC\% & -0.578 & $\mathbf{0 . 0 1 8}^{*}$ \\
FEV1\% & -0.461 & $\mathbf{0 . 0 0 1 *}$ \\
FEV1/FVC\% & 0.575 & $\mathbf{0 . 0 0 0 *}$ \\
\hline
\end{tabular}

$\mathrm{N}=74, *$ Significant at $\mathrm{p}<0.05$.

\subsection{Factors Influencing the Abnormality of Lung Function (FVC \%) among Paddy Farmers}

Multiple regression test was carried out in order to determine the factors that influenced the lung function (FVC \%) among the exposed group after controlling all the confounders in this study. Table 13 showed that there was a significant relationship between the $\mathrm{FVC} \%$ with the duration of exposure to pesticide among the paddy farmers $(\mathrm{p}<0.05)$. This indicated that the duration of exposure to pesticide was the main factor that influenced the abnormalities of FVC \% among studied respondents. The results from this test when adjusted to age and smoking factors also showed that paddy farmers who are working for more than 10 years are likely to have lung function reduction when compared to those who work less than 10 years.

However, based on previous studies, the results were contradicted with this study. A cross sectional study by Çöplü et al. (2005) find that duration of work, which was a proxy for cumulative exposure, had negative association with respiratory symptom such as wheezing.A study conducted by Schenker et al. (2005) also revealed that there was an independent association between the years spent in the agricultural work environment with chronic cough and asthma when exposed to dust, pesticides, gases, fumes, and other airborne. This study concluded that working duration was not the only factor in the reduction of the lung function.

In order to identify the factors to be included in this analysis, a few limitations have been identified from this study. There was no quantitative data and actual measurement on the level of pesticide exposure among the paddy farmers. Additionally, there was information bias available that might influence the result. The using of standardized questionnaires with only crude indicators of exposure could underestimate the potential effects of pesticide exposure. Also, there were limited studies that were done locally on the pesticide exposure to the respiratory health among paddy farmers.

Table 13. Factors influencing the abnormality of lung function (FVC \%) among paddy farmers after controlling all the confounders.

\begin{tabular}{llllll}
\hline Independent & \multicolumn{2}{l}{ FVC\% } & & & \\
\cline { 2 - 6 } Variables & $\boldsymbol{\beta}$ & S.E & p value & PR & $\mathbf{9 5 \% ~ C I ~}$ \\
\hline Constant & -4.068 & 5.47 & 0.999 & - & - \\
Frequency of pesticide exposure (weeks) & -0.183 & 1.224 & 0.881 & 0.833 & $0.076-9.17$ \\
Duration of pesticide exposure(months) & 0.906 & 0.421 & $\mathbf{0 . 0 2 7}$ & $\mathbf{2 . 3 6}$ & $\mathbf{0 . 9 8 - 5 . 4 1}$ \\
Age & 0.411 & 0.168 & 0.140 & 1.51 & $0.70-3.62$ \\
Education level & 0.890 & 0.453 & 0.844 & 1.093 & $0.45-2.6$ \\
Smoking status & 0.973 & 0.459 & 0.070 & 2.793 & $0.49-7.93$ \\
\hline
\end{tabular}

$\mathrm{N}=148, \mathrm{CI}=95 \%$ Confidence Interval, $\beta=$ Regression Coefficient, S.E $=$ Standard Error.

* Significant at $\mathrm{p}<0.05$. 


\section{Conclusion}

Based on the assessment, this study found that paddy farmers who were exposed to high exposure levels of pesticide has shown a significant reduction in lung function $\left(\mathrm{FVC} \%\right.$ and $\mathrm{FEV}_{1} \%$ ) as compared to the office workers. This study concluded that working as a paddy farmer which involves with the usage of pesticide can increase the risk of lung function reduction and has a potential in increasing the prevalence of respiratory symptoms to this worker.

As a recommendation, farmers are advice to have a medical examination periodically from a qualified medical centre. It is important for them to understand the health effects of exposure to pesticide during working activities. Paddy farmers should be provided with adequate training in order to increase the awareness and knowledge due to impact of pesticide exposure and should receive training that includes the instruction about the use and care of appropriate protective equipment, such as protective clothing and respiratory protection.

\section{Acknowledgements}

We would like to express our heartiest appreciation to the citizens of Kampung SawahSempadan, TanjungKarang, Selangor for their cooperation and willingness to participate in this study. The study was fully self-funded. The authors declare that there was no conflict of interest.

\section{Competing Interests Statement}

The authors declare that there are no competing or potential conflicts of interest.

\section{References}

ATS. (1991). American Thoracic Society. Lung Function Testing: Selection of Reference Values and interpretive Strategies. American Review of Respiratory Disease New York. 144, 1202-1224. https://doi.org/10.1164/ajrccm/144.5.1202.

Baharuddin, M. R. B., Sahid, I. B., Noor, M. A. B. M., Sulaiman, N., \& Othman, F. (2011). Pesticide risk assessment: A Study on Inhalation and Dermal Exposure to 2, 4-D and Paraquat among Malaysian Paddy Farmers. Journal of Environmental Science and Health, Part B, 46(7), 600-607. https://doi.org/10.1080/03601234.2011.589309

Bayrami, M., Hashemi, T., Malekirad, A. A., Ashayeri, H., Faraji, F., \&Abdollahi, M. (2012). Electroencephalogram, Cognitive State, Psychological Disorders, Clinical Symptom, and Oxidative Stress in Horticulture Farmers Exposed to Organophosphate Pesticides. Toxicology and Industrial Health, 28(1), 90-96. https://doi.org/10.1177/0748233711407243

Bonner, M. R., Freeman, L. E. B., Hoppin, J. A., Koutros, S., Sandler, D. P., Lynch, C. F., . . Alavanja, M. C. (2016). Occupational Exposure to Pesticides and the Incidence of Lung Cancer in the Agricultural Health Study. Environmental Health Perspectives, 125(4), 544-551. https://doi.org/10.1289/EHP456

Brouwer, M., Huss, A., van der Mark, M., Nijssen, P. C., Mulleners, W. M., Sas, A. M., . . Vermeulen, R. C. (2017). Environmental Exposure to Pesticides and the Risk of Parkinson's Disease in the Netherlands. Environment International, 107, 100-110. https://doi.org/10.1016/j.envint.2017.07.001

Chakraborty, S., Mukherjee, S., Roychoudhury, S., Siddique, S., Lahiri, T., \& Ray, M. R. (2009). Chronic Exposures to Cholinesterase-Inhibiting Pesticides Adversely Affect Respiratory Health of Agricultural Workers in India. Journal of Occupational Health, 51(6), 488-497. https://doi.org/10.1539/joh.L9070.

CHRA. (2000). Chemical Health Risk Assessment Manual. Under the Occupational Safety and Health (Use and Standard of Exposure of Chemicals Hazardous to Health), Department of Occupational Safety and Health, 27-28. Retrieved fromhttp://www.dosh.gov.my/index.php/en/chemical-management/usechh-regulation

Çöplü, L., Demir, A. U., Kalyoncu, A. F., Çöplü, N., Selçuk, Z. T., Enünlü, T., . . Barış, Y. İ. (2005). Lung Health in Workers Exposed to Reed Dust. Respiratory Medicine, 99(4), 421-428. https://doi.org/10.1016/j.rmed.2004.08.015.

Dalvie, M. A., White, N., Raine, R., Myers, J. E., London, L., Thompson, M., \&Christiani, D. (1999). Long-Term Respiratory Health Effects of the Herbicide, Paraquat, among Workers in the Western Cape. Occupational and Environmental Medicine, 56(6), 391-396. http://dx.doi.org/10.1136/oem.56.6.391.

Davidson, K. G., Bersten, A. D., Barr, H. A., Dowling, K. D., Nicholas, T. E., \& Doyle, I. R. (2002). Endotoxin Induces Respiratory Failure and Increases Surfactant Turnover and Respiration Independent of Alveolocapillary Injury in Rats. American Journal of Respiratory and Critical Care Medicine, 165(11), 
1516-1525. https://doi.org/10.1164/rccm.2012030.

Dhananjayan, V., \& Ravichandran, B. (2018). Occupational Health Risk of Farmers Exposed to Pesticides in Agricultural Activities. Current Opinion in Environmental Science \& Health, 4, 31-37. https://doi.org/10.1016/j.coesh.2018.07.005.

Dockery, D. W. (2001). Epidemiologic Evidence of Cardiovascular Effects of Particulate Air Pollution. Environmental Health Perspectives, 109(Suppl 4), 483. https://doi.org/10.1289/ehp.01109s4483.

Dockery, D. W., Pope, C. A., Xu, X., Spengler, J. D., Ware, J. H., Fay, M. E., . . . Speizer, F. E. (1993). An Association between Air Pollution and Mortality in Six US Cities. New England Journal of Medicine, 329(24), 1753-1759. https://doi.org/10.1056/NEJM199312093292401.

Freire, C., Koifman, R. J., Sarcinelli, P. N., Rosa, A. C. S., Clapauch, R., \&Koifman, S. (2013). Long-Term Exposure to Organochlorine Pesticides and Thyroid Status in Adults in A Heavily Contaminated Area in Brazil. Environmental Research, 127, 7-15. https://doi.org/10.1016/j.envres.2013.09.001.

Greene, S. A. (2013). Sittig's Handbook of Pesticides and Agricultural Chemicals. William Andrew.

Halimah, M., Nashriyah, M., Tan, Y. A., \& Ismail, B. (2004). Adsorption and Desorption Study of ${ }^{14} \mathrm{C}$-Chloropyrifos in Two Malaysian Agricultural Soils. Journal of Nuclear and Related Technologies, 1(1), 31-40.

Hashemi, S. M., \&Damalas, C. A. (2010). Farmers' Perceptions of Pesticide Efficacy: Reflections on the Importance of Pest Management Practices Adoption. Journal of Sustainable Agriculture, 35(1), 69-85. https://doi.org/10.1080/10440046.2011.530511.

Hoppin, J. A., Umbach, D. M., London, S. J., Lynch, C. F., Alavanja, M. C., \& Sandler, D. P. (2006). Pesticides Associated with Wheeze among Commercial Pesticide Applicators in the Agricultural Health Study. American Journal of Epidemiology, 163(12), 1129-1137. https://doi.org/10.1093/aje/kwj138.

Kaplan, M. M. (2002). Alanine Aminotransferase Levels: What's Normal?Annals of internal Medicine, 137(1), 49-51. https://doi.org/10.7326/0003-4819-137-1-200207020-00012.

Khan, M., Mahmood, H. Z., \&Damalas, C. A. (2015). Pesticide Use and Risk Perceptions among Farmers in the Cotton Belt of Punjab, Pakistan. Crop Protection, 67, 184-190. https://doi.org/10.1016/j.cropro.2014.10.013.

Khane, R., \& Arora, B. (2015). Study on Effect of Inhaled Pesticides on Pulmonary Function Tests in Farmers. IJSR, 4(6), e2319-7064. Paper ID: SUB155879.

Kodavanti, U. P., Costa, D. L., \& Bromberg, P. A. (1998). Rodent Models of Cardiopulmonary Disease: Their Potential Applicability in Studies of Air Pollutant Susceptibility. Environmental Health Perspectives, 106(Suppl 1), 111-130. https://doi.org/10.1289/ehp.98106s1111.

Krider, S. J., \& Sheldon, R. L. (2000). Pulmonary Function Testing. In K. Fabiano (Ed.), Clinical Assessment in Respiratory Care, 4, 141-160.: Mosby Incorporated.

Lerro, C. C., Freeman, L. E. B., DellaValle, C. T., Kibriya, M. G., Aschebrook-Kilfoy, B., Jasmine, F., ... Alavanja, M. C. (2018). Occupational Pesticide Exposure and Subclinical Hypothyroidism among Male Pesticide Applicators. Occup Environ Med, 75(2), 79-89. http://dx.doi.org/10.1136/oemed-2017-104431

Luo, D., Pu, Y., Tian, H., Wu, W., Sun, X., Zhou, T., . . . Feng, Y. (2017). Association of In Utero Exposure to Organochlorine Pesticides With Thyroid Hormone Levels in Cord Blood of Newborns. Environmental Pollution, 231, 78-86. https://doi.org/10.1016/j.envpol.2017.07.091

Matthews, G. (2008). Attitudes and Behaviours Regarding Use of Crop Protection Products—A Survey of More Than 8500 Smallholders in 26 Countries. Crop Protection, 27(3-5), 834-846. https://doi.org/10.1016/j.cropro.2007.10.013

Mazur, C. S., Marchitti, S. A., \&Zastre, J. (2015). P-glycoprotein Inhibition By The Agricultural Pesticide Propiconazole and Its Hydroxylated Metabolites: Implications For Pesticide-Drug Interactions. Toxicology Letters, 232(1), 37-45. https://doi.org/10.1016/j.toxlet.2014.09.020

McCann, L. (2005). Transaction Costs of Pesticide Policies in Vietnam. Society and Natural Resources, 18(8), 759-766. https://doi.org/10.1080/08941920591005340

McLaughlin, A., \&Mineau, P. (1995). The Impact of Agricultural Practices on Biodiversity. Agriculture, Ecosystems \& Environment, 55(3), 201-212. https://doi.org/10.1016/0167-8809(95)00609-V 
Neghab, M., Momenbella-Fard, M., Naziaghdam, R., Salahshour, N., Kazemi, M., \&Alipour, H. (2014). The Effects of Exposure to Pesticides on the Fecundity Status of Farm Workers Resident in a Rural Region of Fars Province, Southern Iran. Asian Pacific Journal of Tropical Biomedicine, 4(4), 324-328. https://doi.org/10.12980/APJTB.4.2014C586

Nur Naqibah, L., Zailina, H., Nurul Husna, M., Juliana, J., Kee, H.F., KhairulNadiah, Z.A., \&NoorAisyah, H. (2017).Organophospahte Pesticide Mixture Exposure: The Relationship With The Motor Coordination Of Children From Paddy Farming Area In TanjungKarang. Malaysia. Malaysian Journal of Public Health Medicine, Special Volume (1), 115-122

Parveen, S., \&Nakagoshi, N. (2001). An Analysis of Pesticide Use for Rice Pest Management in Bangladesh. Journal of International Development and Cooperation, 8(1), 107-126. Retrieved from http://citeseerx.ist.psu.edu/viewdoc/download?doi=10.1.1.546.2780\&rep=rep1\&type=pdf

Peiris-John, R. J., Ruberu, D. K., Wickremasinghe, A. R., \& van-der-Hoek, W. (2005). Low-Level Exposure to Organophosphate Pesticides Leads to Restrictive Lung Dysfunction. Respiratory Medicine, 99(10), 1319-1324. https://doi.org/10.1016/j.rmed.2005.02.001

Sabarwal, A., Kumar, K., \& Singh, R. P. (2018). Hazardous Effects of Chemical Pesticides On Human Health-Cancer and Other Associated Disorders. Environmental Toxicology and Pharmacology. https://doi.org/10.1016/j.etap.2018.08.018

Salameh, P., Waked, M., Baldi, I., \&Brochard, P. (2005). Spirometric Changes Following the Use of Pesticides. http://www.who.int/iris/handle/10665/116928

Schenker, M. B., Farrar, J. A., Mitchell, D. C., Green, R. S., Samuels, S. J., Lawson, R. J., \& McCurdy, S. A. (2005). Agricultural Dust Exposure and Respiratory Symptoms among California Farm Operators. Journal of Occupational and Environmental Medicine, 47(11), 1157-1166. https://doi.org/10.1097/01.jom.0000181174.02282.0c.

Schenker, M. B., Stoecklin, M., Lee, K., Lupercio, R., Zeballos, R. J., Enright, P., . . Beckett, L. A. (2004). Pulmonary Function and Exercise-Associated Changes with Chronic Low-Level Paraquat Exposure. American Journal of Respiratory and Critical Care Medicine, 170(7), 773-779. https://doi.org/10.1164/rccm.200403-266OC.

Schreinemachers, P., Afari-Sefa, V., Heng, C. H., Dung, P. T. M., Praneetvatakul, S., \& Srinivasan, R. (2015). Safe and Sustainable Crop Protection in Southeast Asia: Status, Challenges and Policy Options. Environmental Science \& Policy, 54, 357-366. https://doi.org/10.1016/j.envsci.2015.07.017.

Schreinemachers, P., Chen, H.-p., Nguyen, T. T. L., Buntong, B., Bouapao, L., Gautam, S., . . Srinivasan, R. (2017). Too Much to Handle? Pesticide Dependence of Smallholder Vegetable Farmers in Southeast Asia. Science of the Total Environment, 593, 470-477. https://doi.org/10.1016/j.scitotenv.2017.03.181

Sham'a, F. A., Skogstad, M., Nijem, K., Bjertness, E., \& Kristensen, P. (2015). Cross-Shift Changes in Lung Function among Palestinian Farmers During High-andLow-Exposure Periods to Pesticides: A Longitudinal Study. Archives of Environmental \& Occupational Health, 70(4), 218-224. https://doi.org/10.1080/19338244.2013.859122.

Shetty, P., Murugan, M., Hiremath, M., \& Sreeja, K. (2010). Farmers Education and Perception on Pesticide Use and Crop Economies in Indian Agriculture. Journal of Experimental Sciences. https://updatepublishing.com/journal/index.php/jes/article/view/1691

Waheed, S., Halsall, C., Sweetman, A. J., Jones, K. C., \& Malik, R. N. (2017). Pesticides Contaminated Dust Exposure, Risk Diagnosis and Exposure Markers in Occupational and Residential Settings of Lahore, $\begin{array}{lllll}\text { Pakistan. Environmental Toxicology and Pharmacology, 56, 375-382. } & \text {. }\end{array}$ https://doi.org/10.1016/j.etap.2017.11.003

Wang, A., Cockburn, M., Ly, T. T., Bronstein, J. M., \& Ritz, B. (2014). The Association between Ambient Exposure to Organophosphates and Parkinson's Disease Risk. Occup Environ Med, Oemed-2013-101394. http://dx.doi.org/10.1136/oemed-2013-101394

WHO. (2009). The WHO Recommended Classification of Pesticides by Hazard and Guidelines to Classification: 2009. World Health Organization. from https://www.who.int/ipcs/publications/pesticides_hazard_2009.pdf

Wiklund, K., Dich, J., \& Holm, L. (1987). Risk of Malignant Lymphoma in Swedish Pesticide Appliers. British 
Journal of Cancer, 56(4), 505. https://doi.org/10.1038/bjc.1987.234

Wilson, C., \&Tisdell, C. (2001). Why Farmers Continue to Use Pesticides Despite Environmental, Health and Sustainability Costs. Ecological Economics, $39(3)$ 449-462. https://doi.org/10.1016/S0921-8009(01)00238-5

Ye, M., Beach, J., Martin, J., \&Senthilselvan, A. (2013). Occupational Pesticide Exposures and Respiratory Health. International Journal of Environmental Research and Public Health, 10(12), 6442-6471. https://doi.org/10.3390/ijerph10126442

\section{Copyrights}

Copyright for this article is retained by the author(s), with first publication rights granted to the journal.

This is an open-access article distributed under the terms and conditions of the Creative Commons Attribution license (http://creativecommons.org/licenses/by/4.0/). 